\title{
Bergsoniana
}

1 | 2021

Reassessing Bergson

\section{Bergson and Our Understanding of Interaction, Constraints and Collective Aspirations}

\section{Emmanuel Picavet}

\section{(2) OpenEdition \\ Journals}

Electronic version

URL: https://journals.openedition.org/bergsoniana/357

DOI: 10.4000/bergsoniana.357

ISSN: 2800-874X

Publisher

Société des amis de Bergson

\section{Electronic reference}

Emmanuel Picavet, "Bergson and Our Understanding of Interaction, Constraints and Collective Aspirations ", Bergsoniana [Online], 1 | 2021, Online since 01 July 2021, connection on 08 November 2021. URL: http://journals.openedition.org/bergsoniana/357 ; DOI: https://doi.org/10.4000/ bergsoniana.357

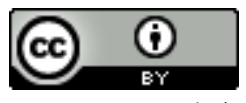

Les contenus de la revue sont mis à disposition selon les termes de la Licence Creative Commons Attribution 4.0 International. 


\title{
BERGSONAND OUR UNDERSTANDING OF INTERACTION, CONSTRAINTS AND COLLECTIVE ASPIRATIONS ${ }^{1}$
}

\author{
Emmanuel PICAVET
}

\section{Introduction}

Re-reading Creative Evolution, The Two Sources of Morality and Religion and the articles in Mind-Energy, among other works, is there any good reason to look for a (more or less) Bergsonian approach to the collective as such? While it would be of little use to question Bergson on the kind of fairly abstract theory of collective norms, decision and powers which has developed between his time and our own, his work is replete with valuable insights about human motivations which connect individuals to social norms and the collective. Should we not, therefore, re-read Bergson

1. The author has benefited from very useful exchanges on the occasion of the Cambridge meeting ("Reassessing Bergson") and he expresses his gratitude to Matyás Moravec for the organisation. This research has benefited from the CHRONOS partnership project on social and normative regulation at FMSH-CEM; the financial support of Groupe SMA in this context is gratefully acknowledged. The author has also benefited from Université Paris 1 Panthéon-Sorbonne's research project on "Impact sur l'internormativité de l'approche par les parties prenantes," hosted by the interdisciplinary Corporate Social Responsibility group within ISJPS; finally, the last version of the article has been discussed in the research group "Normativité environnementale face aux catastrophes climatiques" (DYNAMITE LabEx), February 17 ${ }^{\text {th }}, 2021$ (the author thanks Antoine Mandel and Stéphane Zuber for particularly helpful comments). 
to examine and assess a number of possible directions in social thought, relying on important insights which have hitherto been neglected to some extent and from which something is still to be learned? This is perhaps appropriate, given the centrality and also the lack of clarity of the status of the "individual" in social regulation activities nowadays, in which hypothesised or desirable individual dispositions (or behavioural tendencies) are often derived from ideas or theories about society as a whole.

There is little hope of uncovering radical novelty on the part of Bergson himself in this respect; we are well aware today, thanks to recent scholarship, ${ }^{2}$ that he owes much to the debates of his time in numerous fields. Turning to Bergson is motivated by the fact that we are confronted with many challenges which relate to the shift from the individual will to the collective or social will. Addressing these challenges may benefit from attention to an author who has thought over this transition with particular acuteness. Some of our present-day queries about the individual-collective transition - such as those which pertain to preference aggregation, rational-choice contractarianism, game-theoretic concepts of collective equilibrium, etc. - have no exact counterpart in the Bergsonian corpus. However, a philosophy is not enclosed in the space delimited by the problems which have given the impetus for it, any more than a physical theory remains trapped in the empirical records which account for its emergence. New problems provide occasions to check the relevance of a philosophical architecture on new grounds. This appears to be a possible methodological option for a "re-assessment" of Bergson's philosophy, and it will be taken up in what follows, at first in connection with the foundational aspects of the regulation of complex social systems, then in the field of collective action.

\section{Collective Goals, Human Challenges and the Regulation of Activities}

\section{Organisation and the Guidance of Action}

Inspired by the economic analysis of incentives, sometimes also by the cybernetic paradigm, or else by the cognitivist perspective on the terms of choice (as in contemporary "liberal paternalism" and the "nudges" methodology), the effort to regulate human activities is usually articulated to collective goals. In this respect, we meet formidable problems of collective action today. For example, how is our conduct to be reformed in a way that best fits the reasonable requirements of a limitation of carbon emissions and global warming? How can we limit the growth of perilous inequalities

2. See Worms 2002. 
in democratic states? How can we combine respect for freedom and decent standards of public information? With the purpose of reorienting action so that it brings us closer to certain valid collective objectives, we usually rely on individual routines, attitudes or preferences which are supposed to be more or less stable, hence predictable. Since the results depend on each person's actions, a very modest kind of methodological individualism is hardly facultative: one must understand, in one way or other, what drives people to make choices - which choices, and why. The usual move, then, is to try and encode the individual behaviour and choices into postulated individual values or preferences - sometimes using vocables such as "utility," "desire," "volition," etc., depending on the context and the discipline. Such hypothesised ingredients of personal attitudes thus become the data from which we work and are therefore (at least methodologically) treated as fixed points.

What is thus presupposed, however, might undergo transformations in social life. Whether we deal with routines and stable attitudes which are lent to agents, or with preferences which are deemed "given in advance" - or else with types of preferences, more or less altruistic ones for example - it is not always easy to assimilate the hypotheses that are made with the elements of a hypothetical, ahistorical "human nature" which would be determined independently of shared human experience and social life. On the other hand, how can one take on the tasks of regulating complex systems involving human beings, if one makes no assumption about what makes people's attitudes and behaviour somehow predictable? To address these questions, we must deal with transformation, with a kind of evolution which is inevitably social in its character. Simplifying assumptions are useful for modelling and for the analysis of specific social mechanisms. Nevertheless, the limits of the associated toolkits for the regulation of human systems of interaction are all too obvious in the contemporary world. For example, incentive schemes are, quite clearly, insufficient tools for the purposeful reformation of human interaction. Relying on pre-determined preferences or attitudes as they do, they prove unable to accommodate for the influence of ongoing social interaction on the personal mindset. As a consequence, incentive-based plans often prove unable to meet their objectives. ${ }^{3}$ A clear limitation of the popular and influential incentive-scheme approach to social organisation is its inability to make room for the evolving individual judgment about adequate actions.

3. For a convincing example of field work on this (see Reynaud 2002). 
Those models which seemingly enable one to manipulate incentives in a social system, in order to reach collective goals, really give no clue for that. Individual judgment is not confined to the promotion of predetermined interest. It can benefit from the experience of interaction. Indeed, it is quite plausible to hold, like philosopher Maurice Blondel (Blondel 1893), that collective human action is central to the determination of individual attitudes and efforts. From this perspective, it would seem that individual attitudes co-evolve with human interaction. This opens up the possibility that past social experience conditions human attitudes. Here, of course, lies the pitfall of the hereditary transmission of acquired characters, ratified by Spencer in the days of yore. Naturalistic views of social learning are still influential today, although they display new garments, such as learning in repeated games, the imitation of behavioural traits and the evolutionary selection of the most advantageous among the latter. Bergson's warning in The Two Sources of Morality and Religion is therefore important and still relevant today: "a sociology that thinks it is borrowing from biology the idea of the inheritance of acquired characters only repeats what it has lent." ${ }^{4}$ Bergson stressed that moral progressive steps (acquisitions) are collected in ways of life, in institutions, in language. ${ }^{5}$ As they shape education in a continuous way, they can be transmitted through successive generations, in habits which thus appear "hereditary." This kind of explanation is potentially relevant for the development of a philosophy of social and moral progress, in which the motives for action are not supposed fixed or predetermined. Indeed, Bergson is right in emphasising the coextensive character of social life and (mutual) education. Looking at this the other way round, it must be suspected that those schemes of social organisation which rely on hypothesised, pre-existing motivations, and which are put to use in order to transform social reality, have a potential for blocking or limiting progress in moral awareness. Certainly, this kind of problem plays a

4. “[...] [u]ne sociologie qui s'imagine emprunter à la biologie l'idée d'une transmission héréditaire de l'acquis ne fait que reprendre ce qu'elle avait prêté" (Bergson 2013b, 289). 5. "C'est dans les mœurs, dans les institutions, dans le langage même que se déposent les acquisitions morales ; elles se communiquent ensuite par une éducation de tous les instants ; ainsi passent de génération en génération des habitudes qu'on finit par croire héréditaires" (Bergson 2013b, 289). This is seemingly disharmonious with the occasional strong and general remarks, in Bergson's lectures (or testimonies thereof), about the dangers of overestimating the role of language in human thought - e.g., $16^{\text {th }}$ lecture, April 25 ${ }^{\text {th }}, 1902$ (Bergson 2019, 110) on the overstated propositions in Locke and Taine. See also: $34^{\text {th }}$ and $35^{\text {th }}$ lesson, "Le langage" (Bergson 1990). On language, practical attitudes and social groups, see Balzer (1993, esp. ch. 4). 
role in the widespread contemporary dissatisfaction with economic models and concepts (which rely on pre-determined preferences), at least when they are used as frames for deliberately modified social interaction, education and individual guidance in life (see Arnsperger 2005 and Lacroix 2009).

\section{Creativity and the regulation of action}

Converting models of social interaction into imperative benchmarks, the way we do so often nowadays, has a cost. We risk jeopardising the creative potential of social life as such and its continued capacity to let moral awareness and judgment flourish. If social life is the occasion for creative and continuing education (not just a vehicle for profitable innovation), it can hardly be, at the same time, a regulated system in which individuals are told how they should reason and act so as to make their own interaction predictable and manipulable, thus involuntarily and collectively ensuring that an underlying model become effective (or even true) in some way.

Moreover, in contemporary assessments of the predictability of human behaviour, preferences (understood as choice-oriented, practical dispositions) are seemingly all-important, as evidenced by economic and political models. Naturalistic accounts of the origins and nature of preferences are important, too, when it comes to giving foundations to our beliefs about the predictability of our own behavioural patterns. In this respect, some kind of grounding in instincts, natural desires and needs, or neural patterns, rather than mere whimsical wishes, is useful at a certain level of scientific analysis. In the eyes of Bergson, as Patricia Verdeau recalls, "instinct, in most cases, does not give rise to gradually acquired dispositions" (Verdeau 2007, 371), in contradiction with the Spencerian view of instinct as a product of a gradual evolution. ${ }^{6}$

This opposition was crystallised in the protest against the Spencerian assimilation of psychological forces to mechanical forces, and this proved important in the development of a philosophy of creativity. ${ }^{7}$ According to Bergson, creativity is everywhere, it lies in everything which allows intelligence to supplement instinct, as is clear from Creative Evolution (chapter 2 "On the Divergent Directions in the Evolution of Life"). Intelligence is understood as a pragmatic faculty, and is not confined to

6. The difference was explained in a letter to C. K. Morgan, dated Nov. $21^{\text {st }}, 1912$ (quoted in Verdeau 2007, 371, n.3).

7. For general perspectives about creativity and ethics in contemporary philosophy, starting from Whiteheadean explorations (see Henning 2005). 
speculative knowledge; indeed, instinct and intelligence are described as alternative forms of psychic activity, being two different methods of action on inert matter. ${ }^{8}$ In the context of our discussion, an important feature of Bergson's treatment of intelligence in the creative process of evolution is its ability to infuse successive, qualitatively distinct processes in the existing reality, including the more or less orderly social world. ${ }^{9}$ Thus, inference is incipient invention ${ }^{10}$ and technological inventions are not just elements to be found along the way of progress; rather, they give progress its direction. ${ }^{11}$ Novelty, as it emerges in social experience, has potential consequences for the way we think about society. The transformational role of education and collective learning in society, in particular, makes it difficult to postulate, for the sake of thinking about social regulation, the predominance of fixed attitudes or preferences which are supposed to be given. Such postulated preferences are usually supposed to be housed in a human nature which is what it is and determined quite independently of the history and shared experience (or hopes) that are the fabric of human social life. Starting from Bergsonian premises, this would seem plainly unacceptable. This is not to say, however, that the social life of human beings, for all its creativity and testimonies of the action of intelligence, escapes natural constraints.

Here we are faced with a somewhat ambiguous Bergsonian heritage, since Bergson was the critic of the plasticity lent to instinct, but also the critic of the limits of intelligence, given the importance of instinct for the stability of social organisation. This was a singular argumentative position. Let us mention in this regard The Two Sources of Morality and Religion, in particular Chapter 2 on "Static Religion," about the expression of individuality and the preservation of society, with all its constraints. In the proposed "biological interpretation" of those two essential traits of man, intelligence and sociability, focusing on "perfect" types of association, societies of insects are deemed to be immutable and instinct-driven (Bergson 2013b, 121) while human societies are intelligent and care for substantial choice

8. “[N]ous voyons dans ces deux formes de l'activité psychique, avant tout, deux méthodes différentes d'action sur la matière inerte" (Bergson 2013a, 137).

9. On the complementarity of orderliness and novelty in Bergson's thought, see Grosz (2007).

10. "Sans doute, il y a intelligence partout où il y a inférence ; mais l'inférence, qui consiste en un fléchissement de l'expérience passée dans le sens de l'expérience présente, est déjà un commencement d'invention" (Bergson 2013a, 139).

11. "[...] les inventions qui jalonnent la route du progrès en ont aussi tracé la direction" (Bergson 2013a, 139). 
capabilities of the individuals. This contrast paves the way for Bergson's own interpretation of the (Comtian) complementarity of order and progress. ${ }^{12}$

In Bergson's philosophy, the relationship between the individual and the collective is deeply impacted by the human specificity with respect to novelty and progress. As the effort of invention is delegated to the individual, the latter combines intelligence (as he or she is the agent of intelligence in the human context) with initiative, independence and freedom. ${ }^{13}$ As intelligence has been substituted for instinct, it is no longer possible to rely on instinct as such to equilibrate intelligence. This is the principle of the quest for a virtuality of instinct or a residual form thereof, drawing on imaginary representations, as it surrounds (predominant) intelligence which works with representations. Equilibration is indeed required because novelty is not the whole of social life; stability is important too.

On this account, we should pay attention to the potential role of intelligence as a threat to the continued existence of society. In his vivid portrayal of individual initiative as a rival to social discipline, and intelligence-inspired individual egoism as threat to social order, Bergson deals with the connection of the individual to the collective, and this is connected with sociological doctrines of social organisation as well as to normative theories of the proper articulation of individual and collective claims. What is now called the paradigmatic "problem of collective action" is at the heart of Bergson's analysis of the suggestions of self-serving actions at the individual level, while collective interests, embodied in the social discipline, are simultaneously at stake.

The combination of individual and collective concerns in utilitarian doctrines, for example, is of special interest because utilitarian philosophy relies on both the individual interest and the collective perspective on what

12. 'Des deux conditions posées par Comte, 'ordre' et 'progrès,' l'insecte n'a voulu que l'ordre, tandis que c'est le progrès, parfois exclusif de l'ordre et toujours dû à des initiatives individuelles, que vise une partie au moins de l'humanité. Ces deux types achevés de la vie sociale se font donc pendant et se complètent. Mais on en dirait autant de l'instinct et de l'intelligence, qui les caractérisent respectivement. Replacés dans l'évolution de la vie, ils apparaissent comme deux activités divergentes et complémentaires" (Bergson 2013b, 122). 13. "[...] l'effort d'invention qui se manifeste dans tout le domaine de la vie par la création d'espèces nouvelles a trouvé dans l'humanité seulement le moyen de se continuer par des individus auxquels est dévolue alors, avec l'intelligence, la faculté d'initiative, l'indépendance, la liberté. Si l'intelligence menace maintenant de rompre sur certains points la cohésion sociale, et la société doit subsister, il faut que, sur ces points, il y ait à l'intelligence un contrepoids" (Bergson 2013b, 123-124). 
is suitable for the interests of individuals. Hence a tension within "utility," brilliantly developed in The Two Sources in connection with the fact that what individuals take interest in cannot be foreign to their connection to other people, nor to social concerns. Indeed, the combination of individual and collective concerns would prove quite deceptive, on Bergsonian premises, if it were reduced to the kind of general calculus of interests that is to be found in the historical utilitarian doctrines. The combination really depends upon the reality of human relationships in society. Elsewhere, Bergson stressed that the main defect of utilitarianism is obscurity, because of the complexity of the idea of happiness (by no means a simpler idea than the moral good it is supposed to explain). In addition, Bergson contended that a precise determination of the principle of utilitarian ethics would require its evolution into a morality of sympathy, in which the individual's happiness would coincide with love for others (Bergson 1992, 59-68). If we put the pieces together, this would amount to locating the sources of the limits of utilitarianism in the real nature of social relationships, in which each individual learns to take interest in what happens to the others, and in the interplay of their own motivations on the one hand, social concerns on the other hand. Moving from the "closed" to the "open" dimension of social life in The Two Sources, Bergson is able to portray the open soul but also the process through which the soul is opening itself. This involves reason and humanity which go "divine" in some way, thanks to the action of the great moral characters in human history. This enables the human experience to move far beyond the self-esteem of the group, as it is experienced in group belonging. The intuition which surrounds the workings of intelligence and creative emotion assumes the form of "callings" which operate through human history. Of course, this does not nullify the rational transposition which allows the expression of moral life to be consistent, precise, principled, orderly and amenable to comparisons (Bergson 2013b, 86) but even though moral life is expected to be "rational," it doesn't find its origin, nor its grounding, in pure reason. With respect to the association of the individual and the collective, generally speaking, the difficult intellectual task we face is to allow for the seriousness of the constraints and limits on "intelligence" as Bergson thought of it, even if, at the same time, these constraints rightly seem threatening for humanistic thinking about society. This is not without consequence for social and political philosophy. Bergson understood that social organisation is not fully transparent for human thought. This holds even though he was a thinker of progress and active intelligence in social 
organisation, especially in this type of social organisation (the human one) in which progress is delegated to the individual. In this respect, Bergson's philosophy foreshadowed some of the developments of recent decade, especially those theories of social organisation which have made full use of the concept of "bounded rationality" - to use the phrase which has gained popularity ever since the classic contributions by Herbert Simon, among other authors, put it to the forefront (Simon 1982). These theories have familiarised us with the limits of individual understanding in social contexts, or those of the pragmatic exercise of reason (understood as a faculty), and they have given these limits a central position in social organisation. As a result, the limits of reason as an active faculty — or the constraints to which it is subject - are no longer viewed as anomalies or mere defects; rather, they stand out as important building blocks of sociality as it is. Let us take good notice, however, of the fact that for a very long time, mainstream analyses of institutional organisation and those norms which are enacted in society have, on the contrary, showcased the transparency (for the human mind) of the concepts at work in norm-based social organisation. Isn't the human mind at home in its self-designed world of legal-political concepts? This can be doubted after all. In recent times, the main currents of social thought have emphasised, beyond the technical constraints, the limits of individual consciousness with respect to the understanding of the structure of social life and social mechanisms. It must be noted that this is compatible with the importance of individual consciousness in social organisation.

Consciousness played a crucial role in Bergson's portrayal of choice in the architecture of social life. At its root, consciousness is associated with choice. Bergson, in the Mind-Energy Lectures (first essay), insisted that the most vivid parts of the experience of consciousness are only revealed on certain occasions, all of which are linked to decision-making; consciousness is indeed to be equated with choice in a certain sense. ${ }^{14}$ In Creative Evolution, consciousness is portrayed as the light which is immanent to the area of possible actions. It is more precisely located in the interval between action

14. First essay in Bergson 2009b: "Quels sont, d'autre part, les moments où notre conscience atteint le plus de vivacité ? Ne sont-ce pas les moments de crise intérieure, où nous hésitons entre deux ou plusieurs partis à prendre, où nous sentons que notre avenir sera ce que nous l'aurons fait ? Les variations d'intensité de notre conscience semblent donc bien correspondre à la somme plus ou moins considérable de choix ou, si vous voulez, de création, que nous distribuons sur notre conduite. Tout porte à croire qu'il en est ainsi de la conscience en général. Si conscience signifie mémoire et anticipation, c'est que conscience est synonyme de choix" (Bergson 2009b, 11). 
and representation, and this leads to an "arithmetical" formula which describes the gap between virtual and real activity. Deliberation without effective action allows consciousness to be particularly intense. ${ }^{15}$

In slightly more general terms, in continuity with Bergson's views, should we not make more room for the gradually acquired understanding of the structure of interactions and choices (not just for learning in the face of immediatechallenges and opportunities in action)? It seems that this is indeed a task for consciousness, deviating from action and its pressing, immediate demands. For example, we can think of the necessary understanding of the structure of commitments, which plays a role in institutional forms of responsibility-taking nowadays. For instance, it appears to be a fairly important factor in the "corporate social responsibility" movement, in the fair-trade movement, in emerging concepts that relate to corporate "mission." We may also think of the gradually acquired understanding of the structure of regulation when the latter uses elaborate forms of coordination of intentions (as in the logic of stakeholders), acceptances and institutional intelligence. These are important avenues for research.

Empirical inquiry is important here. The challenges we face, however, are not confined to accuracy in the empirical description of complex phenomena. When commitment and action are structured by descriptions, norms and the connections to institutions (or powers), an interpretative dimension must be taken into account. It is then a matter of choice and therefore, if we follow Bergson, a matter of consciousness. This gives arguments in favour of a non-static, evolutionary view of the constitution of collective action, in a certain contrast with an approach that can be said "aggregative."

\section{Bergson's Intellectual Legacy and the Limits of Our Aggregative Paradigm about Collective Action}

\section{From the Individual to the Collective}

Almost a century after Bergson published his main works, we have become accustomed to abstract thinking about the transition from the individual

15. “Cette inadéquation de l'acte à la représentation est précisément ici ce que nous appelons conscience. [...] En approfondissant ce point, on trouverait que la conscience est la lumière immanente à la zone d'actions possibles ou d'activité virtuelle qui entoure l'action effectivement accomplie par l'être vivant. Elle signifie hésitation ou choix. [...] De ce point de vue, on définirait la conscience de l'être vivant une différence arithmétique entre l'activité virtuelle et l'activité réelle. Elle mesure l'écart entre la représentation et l'action" (Bergson 1992, 59-68). An additional development is the parallel between virtual and real action on the one hand, sensation and perception on the other hand — see Bergson (2009a). 
to the collective. The "aggregative" paradigm about this transition is well represented by "social choice theory" (or collective choice theory), following from the work of Borda and Condorcet, as it has been profoundly reshaped in the $20^{\text {th }}$ century by Kenneth Joseph Arrow and other researchers in various disciplines (Arrow 1951). This paradigm is useful for the analysis of procedures (voting procedures for example). It meets its limits whenever deliberation and the process of choice turn out to matter as such.

Indeed, deliberation is a vehicle for creative dimensions in individual and social life. It brings gradually awakened consciousness into play, especially with respect to the meaning and scope of the criteria of choice. This proves essential whenever we must assess their relative importance, or the desirable hierarchies to be created between various criteria of different types. Beyond explicit or formal deliberation, the meeting points between evolving individual attitudes appear to be decisive in the formation of collective action, collective judgments, collective statements and other inherently "collective" objects. Collective action, however, is partly structured by institutions and institutional goals must be invested with stable goals. Thus, in the fairly holistic perspective of institutional operations research, the ability of institutions to articulate their own goals or values and to pursue them rationally can be contrasted with the potential disorderliness which might result from shifting preferences (D'Aumale 1968, 21-22). In a more individualistic paradigm, however, the quest for the "collective" relies on preferences or value judgments that are supposedly "given" in the individual layer of reality, even though they can be supposed to be just any system of preferences or judgments, provided pairwise comparison formal requirements are met: these include exhaustivity ("completeness") and consistency (transitivity or the absence of cycle) in pairwise comparisons. This is illustrated by the so-called "multiprofile" mainstream approach to collective choice in contemporary social and political theory. ${ }^{16}$ This is a limitation, and we may think that a less abstract perspective on the constitution of the collective - like Bergson's - also has its role to play. In

16. This (Arrowian) approach has been the object of economist Serge-Christophe Kolm's stern criticism, on account of its supposedly abstract character, which makes it incapable of relying on real-world human values and preferences; see (Kolm 1986). See also Kolm's illuminating remarks about the necessity to try and understand evolving preferences whose dynamics is correlated with perceptions, personal experience and the inner life (Kolm 1984, 31). These methodological guidelines can be paralleled with the distinctive importance given to personal experience in economic and political life (and in the evolution of individual judgment) by Thomas Piketty — for an early example, see (Piketty 1995). 
this sense, it is possible to stress that Bergson's social theory gives a transversal perspective on the current political and philosophical debate about liberalism and the philosophies of "community" which crucially revolve around the structure of personal values and choices. ${ }^{17}$ Axiological dynamics also has a hermeneutical side. Indeed, the gradual social elaboration of descriptions that structure and guide collective action or collective attitudes must be taken into account for both social and moral reasons. ${ }^{18}$ For example, are the 2019 Hong Kong events "troubles" that involve the threat of chaos, or even "terrorism," or should they be described as successive stages in a fight for freedom, involving the use of various strategies of legitimate resistance to power? Depending on the chosen description, distinct attitudes can be expected. International attitudes (supportive of not) depend on such descriptions by and large. The same can be said of their evolution in response to the acquisition of information, reflection, and the possible refinement of value judgments over time. Of course, we can also say (the other way round) that the descriptions that are put forward derive from the attitudes we adopt; this, however, should not mask the specific impact of descriptions and their evolution on the formation of individual attitudes and collective action. We would get only a very limited grasp of questions of this kind, should we rely on fixed preferences. Moreover, the dynamics of attitudes and values is closely associated with interdependence, and the latter reveals itself only if we reject the notion of purely "individual" attitudes and values. In institutional settings, the interpretation of standards or principles is a guiding force in the process. It usually involves a number of non-obvious choices. The difficulty of interpretative choices has occasionally provided authority-supportive reasons in the past ${ }^{19}$ but this problem is often neglected nowadays. This causes hermeneutic troubles in social life and political attitudes. For example, nothing forces us to interpret tariff rules as constitutive of a "trade war." In the enactment of this kind of rules, we find a strategic dimension which can vaguely be reminiscent of war, and there also exist associations of ideas between protectionism and distrust on the international scene, due to

17. See, in the context of a discussion of Bergson's views about the "open society" (Fritzi 2002, 247).

18. In contemporary philosophy, Bergson is still a classic source for dual (social and moral) thinking about duty. See for example Santos $(2012,225)$.

19. For a classic example, see the restitution of the 1710 dialogue by Andrew Michael Ramsay, Entretien de Fénelon et de M. de Ramsai (Ramsay, 1723). In Bausset's narrative of the successive events in Ramsay's life, leading to the Cambrai dialogues, perplexity about textual interpretation plays a prominent role (Bausset 1850, 344). 
significant historical episodes. This being said, a substantial connection is far from obvious. If one chooses to accept its reality, the formation of collective attitudes towards new customs tariffs is, ab initio, negatively framed: no one likes war, no one trusts those who cause it. The collective attitude would be different if the interpretation gave priority to autonomous decision-making in the national economy, for example.

In Bergson's writing, the comparison of the artist and the moralist (Mind-Energy, first essay) gave him the opportunity to highlight, in the structuring of action in society, the dimension of mutual influence. Thus, the creativity that manifests itself in the correlation of evolving attitudes to one another in society came to the front. Such is the concrete foundation of the celebrated Bergsonian model of the propagation of a moral outlook in society. ${ }^{20}$ Bergson wrote about those great men ("gens de bien") whose simple and inventive heroism has opened new routes to virtue. The analysis of this kind of process came close to the study of emotions and their role in the moral statements which are transmitted down through successive generations. ${ }^{21}$ Creativity does not make constraints redundant; rather, it complements them. Individual intelligence (understanding, analysis) and collective intelligence (sharing, collaboration) are able to make progress in deciphering the constraints which are binding in human interaction, and which partially structure the latter. Thus, the limits of information and its treatment, the limitation of the ability to get a clear mind about the best available reasons, the difficulties which are specific to the constitution of collective actions represent real challenges for human action in society. Taking such constraints into account has become a major issue in the contemporary world, owing to the growing awareness of the necessity to act in consideration of impacts and liabilities which far exceed responsibilities which are firmly established in the institutional and normative logic. Important examples can be found in the actions we

20. Bergson wrote: “[...] créateur par excellence est celui dont l'action, intense ellemême, est capable d'intensifier aussi l'action des autres hommes et d'allumer, généreuse, des foyers de générosité " (Bergson 2009b, 25). See, on these matters Amalric (2012). On the cognitive side of the problematic, this interesting aspect of Bergsonism could be reexamined, starting from an examination of the evolution of beliefs among agents who are confident in the expertise of one another. On the dynamic aspects, see Lehrer and Wagner (1981, esp. I, ch. 4, \$2). A critical discussion of the global perspectives on ethical attitudes in contemporary political theory can be found in Küng (2002, 122-133).

21. See ch. 1 about moral obligation (Bergson 2013a, 47). The comparison between the Stoa and Christianity, and the subsequent evocation of Socrates, are good illustrations of the interplay of emotions and moral outlooks (Bergson 2013a, 59 sq.). 
(sometimes) take to limit global warming, or to avoid alignment on the worst options with respect to environmental and social issues, in spite of the predominant logic of competitive relocations of industrial activities and tax payment. There is also a fundamental link between the recognition of constraints, the justification of the forms of collective organisation and the understanding of the opportunities for agreement or collaboration. This accounts for the continued - indeed, renewed — influence of classical contractarian political theory in applied reasonings about collective or institutional responsibility, and about constructive decision-making with a plurality of stakeholders. For these different reasons, in order to be able to think collective action, one needs to take into account the dimension of the choice at the level of representations, descriptions and conscious build-up of attitudes. I suggest that this can be implemented as indicated by the first essay in Mind-Energy. Taking the remembrance of past actions into account and learning from past results lies at the heart of choice and expectations, as described by Bergson in a precise way. ${ }^{22}$ Clearly enough, such operations are integral parts of collective tasks in response to evolving ideas about responsibility-taking.

\section{Solidarity, Fraternity and Duration in Society}

Locating the individual use of reason within the collective also matters to address solidarity in a relevant way. Bergson was a thinker of the transition from solidarity (as consolidated in the "first morality") to the ideals of fraternity (at the heart of a second morality). But how can we make sure that fraternity does not remain trapped in a purely declarative posture, and instead inspires institutions that are really capable of exploring the practical realities of solidarity? Again, this is a challenge we are faced with in contemporary social philosophy. Its relevance for practical matters is connected with the way value-laden individual efforts take on a social dimension through the action of institutions; as Raymond Ruyer stressed, this transformation is key to increased effective power in human action, with all the lateral risks for the "authenticity" of results (Ruyer 1948, 81). From a Bergsonian viewpoint, it is necessary to articulate the naturalness of the individual and the group to the social destination of humanity. Is Bergson better than Léon Bourgeois on this score (bearing in mind how Bourgeois

22. “[...] si, comme nous le disions, la conscience retient le passé et anticipe l'avenir, c'est précisément, sans doute, parce qu' elle est appelée à effectuer un choix : pour choisir, il faut penser à ce qu'on pourra faire et se remémorer les conséquences, avantageuses ou nuisibles, de ce qu’on a déjà fait ; il faut prévoir et il faut se souvenir" (Bergson 2009b, 10). 
was successfully criticised by Ferdinand Buisson in this respect)? Bergson was unquestionably able to distinguish between necessity and freedom, and he did so in a way that proved useful for the collective treatment of individual creativity in society, as can be seen in Mind-Energy (first essay), where he examined how societies are tentatively giving individuals a role within the collective, while putting individual energies together and allowing separate efforts jointly to be eased (Bergson 2009b, 2526). He later dealt with contradictions and antagonisms among societies, but here, Bergson further expressed a distinctive and interesting concern for the integrity of the will. He stressed, in a way reminiscent of Kant's views, the compatibility of antagonism with the mutual adjustment of individual wills, or even entire societies, within larger communities. Again, this kind of process was supposed to nurture creativity in the ordinary sense (with its components of invention and effort). Bergson was able to give individual intelligence a role in the collective movement without omitting the limitations of each individual's point of view, especially in the "first morality," which is typically elaborated by and for small groups (Bergson 2013b, ch. 1). The resulting picture of human life is rather complex, since hostility between groups turns out to be associated with the gradual alleviation of constraints in human life, and the threats posed by intelligence to community life. In The Two Sources, Bergson emphasised in a particularly clear way the part of freedom and that of convention, the role of the free choice of representations which is allied to constraints when it comes to addressing the issue of responsibility with regard to a definite and recognised interest. This enabled the author to formulate important insights about the complexity of responsibility, which originates in realworld solidarity, a good distance from the abstract, deceptively simple model of independent individual activity (Bergson 2013b, 127-129). Collective action and society itself are meant to be viable over time in some sense, or "sustainable" in our contemporary jargon. From this point of view, I suggest that part of Bergson's interesting legacy can be found in economist Michel Vatés considerations about the revelation of duration by the collective. His contribution stressed the predominance of duration over time whenever we are interested in the social dimension of human action, which inevitably relies on the continued existence and development of groups. In a theory of the derived existence of institutions, Vaté also portrayed institutions as vehicles of collective acts and commitments (Vaté 1976, especially 29 and 57-58). 


\section{Conclusion}

The legacy of Bergson's philosophy in connection with collective thinking about the collective side of human life and action is well worth investigating. In this philosophy, it can be observed that creativity, responsibilities and mutual responsiveness in social interaction, as well as the awareness of shared representations and interpretations, make for a highly interconnected set of notions, which can be useful to make progress in the grasp of collective action problems. The spiritual interpretation of evolution that Bergson put forward enabled him to connect consciousness, choice and intelligence with the momentum of social life. This gives a distinctive interest to his classic works in addition to the otherwise significant connections between his work and the philosophical and scientific ideas of his time. Bergson's views about the kind of progress which infuses social life is still inspiring and it challenges the impoverishing perspectives which follow from narrow assumptions about pre-determined values, attitudes or preferences. Working with a broad, inclusive concept of society, Bergson was able to highlight some of the features of action and deliberation which have become essential nodes - both methodologically and practically - in the network of contemporary perplexities and efforts which relate to responsible initiative and planned collective action. Reassessing the permanent value of important Bergsonian insights might thus bring light to a number of perplexing issues which affect substantial debates in our times and, more often than not, hinder collective progress.

\section{Bibliography}

Amalric, David. 2012. "Ouvrir le clos: politique bergsonienne et sens pratique des Deux sources." In Annales bergsoniennes $V$ Bergson et la politique: de Jaurès à aujourd'hui, edited by Frédéric Worms, 267-296. Paris: Presses universitaires de France.

Arnsperger, Christian. 2005. Critique de l'existence capitaliste. Paris: Cerf. Arrow, Kenneth Joseph. 1951. Social Choice and Individual Values. New York: Wiley.

Balzer, Wolfgang. 1993. Soziale Institutionen. Berlin and New York: Walter de Gruyter.

Bausset. 1850. Histoire de Fénelon. Paris: Jacques Lecoffre et Cie.

Bergson, Henri. 1990. Cours, I Leçons de psychologie et de métaphysique, edited by Henri Hude with Jean-Louis Dumas. Paris: Presses universitaires de France. 
Bergson, Henri. 1992. Cours II. Paris : Presses universitaires de France.

Bergson, Henri. 2009a. Matière et mémoire. Paris: Presses universitaires de France.

Bergson, Henri. 2009b. L'Énergie spirituelle. Paris: Presses universitaires de France.

Bergson, Henri. 2013a. L'Évolution créatrice. Paris: Presses universitaires de France.

Bergson, Henri. 2013b. Les Deux sources de la morale et de la religion. Paris: Presses universitaires de France.

Bergson, Henri. 2019. L'Idée de temps. Cours au Collège de France. Paris: Presses universitaires de France.

Blondel, Maurice. 1893. L'Action: essai d'une critique de la vie et d'une science de la pratique. Paris: Félix Alcan.

D’Aumale, Geoffroy. 1968. La Programmation des décisions, Paris: Presses universitaires de France.

Fritzi, Gregor. 2002. "Société et morale sous l'angle de la philosophie de la vie. Une comparaison franco-allemande." In Annales Bergsoniennes I. Bergson dans le siècle, edited by Frédéric Worms, Paris: Presses universitaires de France.

Grosz, Elizabeth. 2007. "Deleuze, Bergson and the concept of life." Revue internationale de philosophie 241: 287-300.

Henning, Brian. 2005. The Ethics of Creativity. Pittsburgh: Pittsburgh University Press.

Kolm, Serge-Christophe. 1984. Le libéralisme moderne. Paris: Presses universitaires de France.

Kolm, Serge-Christophe. 1986. Philosophie de l'économie. Paris: Le Seuil.

Küng, Hans. 2002. "Zur Problematik von Weltpolitik, Weltstaat und Weltethos." In Weltrepublik - Globalisierung und Demokratie, edited by Stefan Gosepath and Jean-Christophe Merle. Munich: C. H. Beck.

Lacroix, André. 2009. Critique de la raison économiste — L'économie n'est pas une science morale. Montréal: Liber.

Lehrer, Keith and Carl Wagner. 1981. Rational Consensus in Science and Society. Dordrecht and Boston: D. Reidel Publishing Company.

Piketty, Thomas. 1995. "Social Mobility and Redistributive Politics." The Quarterly Journal of Economics 110: 551-584. 
Ramsay, Andrew Michael. 1723. Histoire de la vie et des ouvrages de M. de Fénelon, archevêque de Cambrai. La Haye: Frères Vaillant et N. Prevost. Reynaud, Bénédicte. 2002. Operating Rules in Organizations. Basingstoke: Palgrave.

Verdeau, Patricia. 2007. "Bergson et Spencer." In Annales bergsoniennes III. Bergson et la science, edited by Giuseppe Bianco et al., 361-377. Paris: Presses universitaires de France.

Ruyer, Raymond. 1948. Le Monde des valeurs. Paris: Éditions Montaigne. Santos, José Manuel. 2012. Introdução à ética. Lisboa: Documenta.

Simon, Herbert. 1982. Models of Bounded Rationality. Cambridge, Mass.: MIT Press.

Vaté, Michel. 1976. Le Temps de la décision. Lyon: Presses universitaires de Lyon.

Worms, Frédéric. 2002. Annales bergsoniennes I : Bergson dans le siècle. Paris: Presses universitaires de France.

Emmanuel Picavet is a professor of philosophy (applied ethics) at Université Paris 1 Panthéon-Sorbonne (Philosophy faculty [UFR 10]) where he is also the chairman of the Centre de philosophie contemporaine de la Sorbonne within the Institut des Sciences Philosophique et Juridique de la Sorbonne (Université Paris 1 Panthéon-Sorbonne \& CNRS). He is co-chairman of the "Éthique et finance" chair, Fondation Maison des Sciences de l'Homme, Collège d'Études Mondiales (Paris). He supervises the Sorbonne Philosophy \& Society Master's degree curriculum. He acts as France's delegate in FISP's Comité directeur. His personal work is mainly about norms, dialogues, and decision-making.

\footnotetext{
Abstract: Bergson's work is full of insights of the highest interest about motives which connect human beings to social norms and the collective. Revisiting Bergson is motivated by the fact that we are confronted with many challenges which relate to the transition from the individual will to the collective or social will. It is reasonable to think that the examination of these challenges may benefit from the renewed reading of an author who has examined this transition with particular acuteness. Bergson was the critic of the plasticity lent to instinct, but also the critic of the limits of intelligence, given the importance of instinct and its derivatives for the stability of social organisation. This is a singular argumentative position. Amalgamating the constraints on individual and collective intelligence, Bergson understood that social organisation is not transparent for thought. The resulting perspective on the collective is well worth a new assessment. In particular, turning to this philosophy of evolution and openness might prove important
} 
for contemporary developments which aim at reaching a better understanding of the virtualities of jointly evolving preferences or value judgments in society, thus escaping a number of collective-action shortcomings associated with the assignment of pre-defined preferences to individuals.

Keywords: Henri Bergson, collectivity, individuality, norms, organisation.

Mots-clés : L'œuvre de Bergson regorge d'idées du plus haut intérêt sur les motivations qui lient les êtres humains aux normes sociales et au collectif. Revisiter Bergson est motivé par le fait que nous sommes confrontés à de nombreux défis liés au passage de la volonté individuelle à la volonté collective ou sociale. Il est raisonnable de penser que l'examen de ces défis peut bénéficier de la lecture renouvelée d'un auteur qui a examiné cette transition avec une acuité particulière. Bergson a été le critique de la plasticité prêtée à l'instinct, mais aussi le critique des limites de l'intelligence, étant donné l'importance de l'instinct et de ses dérivés pour la stabilité de l'organisation sociale. Il s'agit là d'une position argumentative singulière. En fusionnant les contraintes de l'intelligence individuelle et collective, Bergson a compris que l'organisation sociale n'est pas transparente pour la pensée. La perspective sur le collectif qui en résulte mérite bien une nouvelle évaluation. En particulier, le recours à cette philosophie de l'évolution et de l'ouverture pourrait s'avérer important pour les développements contemporains qui visent à mieux comprendre les virtualités des préférences ou des jugements de valeur évoluant conjointement dans la société, échappant ainsi à un certain nombre de défauts de l'action collective associés à l'attribution de préférences prédéfinies aux individus.

Mots-clés: Henri Bergson, collectivité, individualité, normes, organisation. 
